Journal of Agricultural Sciences
(Tarim Bilimleri Dergisi)

\title{
Potential Aphid (Hemiptera: Aphididae) Vectors of Plum-pox Virus (Virus:Potyviridae) and Status of Sharka Disease in Stone Fruit Orchards in the East Mediterranean Region of Turkey
}

\author{
Adalet HAZIR ${ }^{\mathbf{a}^{*}}$ (D), Melike YURTMEN ${ }^{\mathrm{a}}$ (D), Hakan FIDAN ${ }^{\mathbf{b}}$ (D) \\ ${ }^{a}$ Biological Control Research Institute-Adana, TURKEY

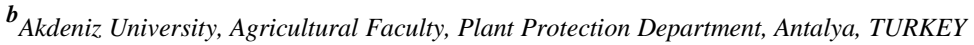

\section{ARTICLE INFO}

Research Article

Corresponding Author: Adalet HAZIR, E-mail: adalet.hazir@tarimorman.gov.tr

Received: 17 April 2020 / Revised: 12 June 2020 / Accepted: 24 June 2020 / Online: 04 December 2021

\section{ABSTRACT}

This study was conducted in stone fruit orchards in five provinces of the East Mediterranean Region of Turkey between the years of 2009-2011. The aim of the study was to determine the potential aphid vectors of the quarantine pathogen PPV (plum pox virus, family Potyviridae) that causes serious yield losses. During the surveys, 542 orchard/nurseries were sampled and 6 aphid species (Hemiptera: Aphididae) [Brachycaudus persicae (Passerini,1860), B. helichrysi (Kaltenbach, 1843), B. cardui (Linnaeus, 1758), Hyalopterus pruni (Geoffroy, 1762), Myzus persicae (Sulzer, 1776) and M.cerasi (Fabricius, 1775)] from stone fruit trees and 4 aphid species [Aphis craccivora (Koch, 1854), A. fabae Scopoli 1763, A. gossypii Glover 1877, A. nasturtii Kaltenbach 1843)]

Keywords: Aphid vectors, Plum-pox virus, Sharka from weeds that were known as the efficient vectors of PPV were detected in the stone fruit orchards. Stone fruit samples (flower, leaf, fruit), weed samples and aphid samples were tested by DAS-ELISA to determine the presence of PPV. PPV infected samples that resulted uncertain from DAS-ELISA were processed to conventional RT-PCR (Reverse Transcription Polymerase Chain Reaction) to finalize the decision of PPV presence. A total of 8 orchards were resulted as PPV-infected with both analyzing methods in the region. Three of these orchards were infected with aphids as well. B.cardui collected from the PPV-infected orchard in Hatay-Samandağ were also run to analyse for the presence of PPV and resulted virus positive.

(C) Ankara University, Faculty of Agriculture

\section{Introduction}

The majority of plant viruses rely on insect vectors for transmission. Acquisition and inoculation of viruses occurs during feeding activity of specific vectors (Stafford et al. 2012). Among insect vectors, aphids are the most common and efficient vectors owing to piercing-sucking mouthparts that provide transmission of the virus to healthy plants. Viruses were classified as stylet- borne (carried at the tips of the stylets, non-persistent) or circulative (ingested by aphids and circulated through the hemolymph, persistent) (Pirone \& Harris 1977). Unlike some other viruses, PPV (plum pox virus, family Potyviridae) is not persistent in the aphid and is transferred from the mouthparts of the aphid between plants non-persistently. PPV, the causal agent of sharka virus disease, is one of the devastating organisms that threatens fruit production of stone fruits. Severe fruit deformation and premature fruit dropping is seen in the infected orchards that cause serious economic losses (Figure 1).

Sharka disease is listed in the domestic and external quarantine list of Turkey. The disease was first detected on plums in Edirne in 1969 in Turkey (Sahtiyanc1 1969) but had a slow dispersion since that time. Following the first report, Elibuyuk (2003) detected PPV-M strain in 10 home gardens in Ankara region in apricot, plum and peach trees between 1995 and 2002. Afterwards, Koc \& Baloglu (2006); Candresse (2007); Ulubas Serce et al. (2009); Akbas et al. (2011); Caglayan et al. (2013); Ceylan et al. (2014); Çağlayan \& Yurdakul (2017) and Yurtmen et al. (2017) conducted studies related to the disease.

The foremost inoculum source of the virus is infected prunus trees. Wild woody and herbaceous hosts are also widespread and are potential reservoirs of the disease. Virus is transmitted from infected trees to healthy ones by means of grafting, infected propagation material and aphids (Celetti et al. 2008). Natural transmission of the virus is mediated by Aphids (Aphididae) in non-persistent manner. Aphids can acquire the virus in probes as short as 30 seconds, and can transmit for up to 1 hour (Labonne et al. 1995). Myzus persicae, Aphis gossypii, A. spiraecola, A. fabae, Brachycaudus persicae and Hyalopterus pruni transmitted PPV under laboratory conditions (Avinent et al. 1994; Gildow et al. 2004). Currently, up to 20 aphid species are known to transmit PPV (Levy et al. 2000; Labonne \& Dallot 2006). Apart from cultivated Prunus, several weed species have been 
identified as PPV herbaceous hosts under experimental and under field conditions (Milusheva \& Rankova 2002; Viršček 2004; Celetti et al. 2008). As well as being a possible reservoir of PPV, weeds play an important role as being host plant for aphid vectors.
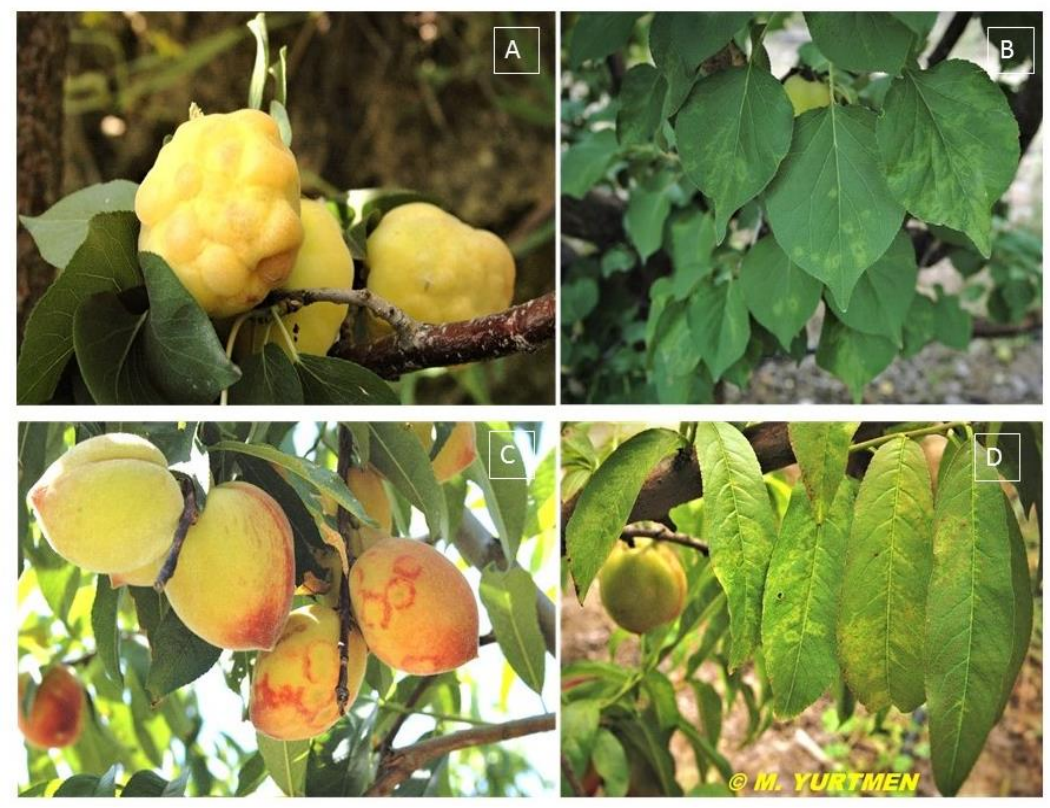

Figure 1- Sharka disease symptoms observed on apricot fruits (A), apricot leaves (B), peach fruits (C) and peach leaves (D)

In this study, the actual status of the disease in stone fruit orchards of eastern Mediterranean region were revealed. Aphid species were detected on Prunus trees and on weed species. Besides, weed species as possible reservoir of PPV both in the infected and non-infected orchards were detected. In this manner the risk of new introductions by aphid vectors were evaluated.

\section{Material and Methods}

Extensive surveys to detect PPV infection, aphid species composition in the region, potential vector aphids and weeds that host to aphids and the virus were performed yearly in spring and autumn between the years of 2009 and 2011.

\subsection{Field surveys and samples}

The study was carried out on stone fruit orchards (apricot, peach, nectarine, plum, cherry) in the largest Prunus cultivating areas in Adana (Ceyhan, Seyhan, Yüreğir, Karataş), Mersin (Arslanköy, Değirmendere, Çiviçukuru, Dikilitaş, Tarsus, Çamtepe, Yeşilovacık, Mut), Hatay (Samandağ, İskenderun), Kahramanmaraş (Andırın, Çokaklı, Merkez) and Osmaniye provinces in the Eastern Mediterranean Region of Turkey. Number of survey orchards was determined according to Bora and Karaca (1970). During the surveys, the minimum amount $(0.01 \%)$ of total tree entity of the province were considered but was expanded as much as possible. As much flower, leaf and fruit as possible were sampled in the randomly selected orchards (Barnett 1986).

\subsection{Method}

\subsubsection{Detection of $P P V$}

During a 3 year period, stone fruit orchards were visually inspected for PPV symptoms. Samples of flowers, leaves and fruits from the symptomatic and asymptomatic trees were collected in Spring and Autumn periods. Each symptomatic plant, weeds and aphids were collected individually. If no symptom expression of sharka was seen, samples were taken from ten trees; one flower, one leaf and one fruit sample from four direction of the tree. The number of samples in the orchards were varied according to the size of the orchards, number of the symptomatic plants and the presence of the aphid vector and weeds hosting aphid species. In case of the presence of all these parameters, number of the subsampling were increased in the subjected orchard.

These samples were tested for the presence of PPV. Double Antibody Sandwich Enzyme Linked Immuno Sorbent Assay (DAS-ELISA) method was used for the serological identification of the virus by using commercial PPV kit (Bioreba-PPV). The results were evaluated both visually and by spectrophotometer at $405 \mathrm{~nm}$ wavelength. Two-fold or more of negative control value was accepted as positive for PPV. The samples resulted serologically as being PPV-positive or PPV-suspected were run to conventional RT-PCR (Reverse Transcriptase Polymerase Chain Reaction), molecularly in order to clarify the results. As well 
as plant samples of Prunus, the aphid species collected from suspected orchards were subjected to serological and molecular screening against PPV. The weeds collected from orchards were also tested for the presence of PPV.

\subsubsection{Detection of aphids}

Twigs and leaves of Prunus trees infested with aphids were cut and wrapped with paper, then were placed in a plastic bag and brought into laboratory in cold chain once a week. Weeds were uprooted for accurate identification. The aphid samples were taken not only from symptomatic trees but also from healthy ones and were stored in $70 \%$ alcohol for future identification. For peach trunk aphid, Pterochloroides persicae; samples were collected from the trunk and thick branches of the trees directly by a fine brush and placed in $70 \%$ ethanol in glass vials in the orchard. Nymphs were reared into adults in cages in the controlled rearing rooms adjusted $25 \pm 2{ }^{\circ} \mathrm{C}$ temperature and $70 \pm 10 \%$ relative humidity.

\subsubsection{Identification}

Aphid adults were identified into species by Dr. Işıl Özdemir (Ankara Plant Protection Central Research Institute) and weeds by Dr. Eda Aksoy (Directorate of Plant Biodiversity, Geofit Research and Training Center). Coccinellidae species were identified by Prof. Dr. Nedim Uygun (Çukurova University, Agriculture Faculty, Plant Protection Department-Retired). Identification of Neuroptera species were made by Prof. Dr. Faruk Özgür (Çukurova University, Agriculture Faculty, Plant Protection Department-Retired). Masaru Nishikawa (Ehime University; Entomological Laboratory, Matsuyama, Japan) identified the Forficulidae species.

\section{Results and Discussion}

\subsection{Detection of PPV in stone fruit orchards}

In the first year of the study (2009), five hectare of nectarine/peach mixed orchard located in Adana were found PPV-infected among 143 orchards sampled. In the second year, two PPV infected orchards were detected among 202 orchards sampled. The 0.5 hectares nectarine orchard located in Samandağ/Hatay and 8 hectares nectarine orchard in İskenderun/Hatay were eradicated. In 2011, two apricot and one peach orchards located in Hatay were also found infected with PPV. In the same year, 0.5 hectares of apricot orchard in Akdeniz district of Mersin and 1.5 hectares of plum orchard in Yeşilovacık districts of Mersin were found contaminated with sharka disease among 197 orchards sampled in 2011. The infection rates were shown in Table 1. All PPV infected orchards detected between 2009 and 2011 were eradicated by their owners.

Table 1- PPV infection rates of orchards sampled in 2009, 2010 and 2011 in East Mediterranean Region

\begin{tabular}{llll}
\hline Year & $\begin{array}{l}\text { Number of } \\
\text { orchards sampled }\end{array}$ & $\begin{array}{l}\text { Number of } \\
\text { orchards } \\
\text { PPV infected }\end{array}$ & $\begin{array}{l}\text { Infection } \\
\text { rate of sampled } \\
\text { orchards (\%) }\end{array}$ \\
\hline 2009 & 143 & 1 & 0.70 \\
2010 & 202 & 2 & 0.99 \\
2011 & 197 & 5 & 2.54 \\
\hline TOTAL & 542 & 8 & 1.47 \\
\hline
\end{tabular}

\subsection{Detection of aphid species}

In order to detect the current status of aphid vectors in stone fruit orchards, surveys were conducted in the orchards of peach, apricot, nectarine, plum, cherry and almond for three years long. Aphid colonies were collected from both Prunus trees and from weeds in and around these orchards whether they were PPV-symptomatic or not. After that, the aphids were identified into species and listed in Table 2.

In the study, a total of 19 aphid species were collected between the years of 2009 and 2011. Of the total amount, seven species-Brachycaudus persicae, B. cardui, B. helichrysi, Hyalopterus pruni, Pterochloroides persicae, Myzus persicae, M. cerasi were collected from stone fruit trees. Eleven species including Aphis pisum, A. craccivora, A. fabae, A. fabae solanella, A. gossypii, A. nasturtii, A. rumicis, Brevicoryne brassicae, Hayhurstia atriplicis, Lipaphis erysimi, Uroleucon (Uromelan) jaceae were derived from weeds, and a species-Macrosiphum rosae- was on rose (Table 1). Among these species, A. gossypii, A. craccivora, A. fabae, A. nasturtii, B. persicae, B. helichrysi, B. cardui, H.pruni, M. persicae, and M. cerasi were ranked among the vectors of PPV with variable efficiency (Kunze \& Krczal 1971; Avinent et al. 1994; Labonne et al. 1995; Levy et al. 2000; Pribek 2001; Gildow et al. 2004). Therefore, natural spread of Sharka disease by aphid vectors to the short distance exist potentially in the region. 
Table 2- Aphid species detected in stone fruit orchards in 2009, 2010, 2011 and their vector status

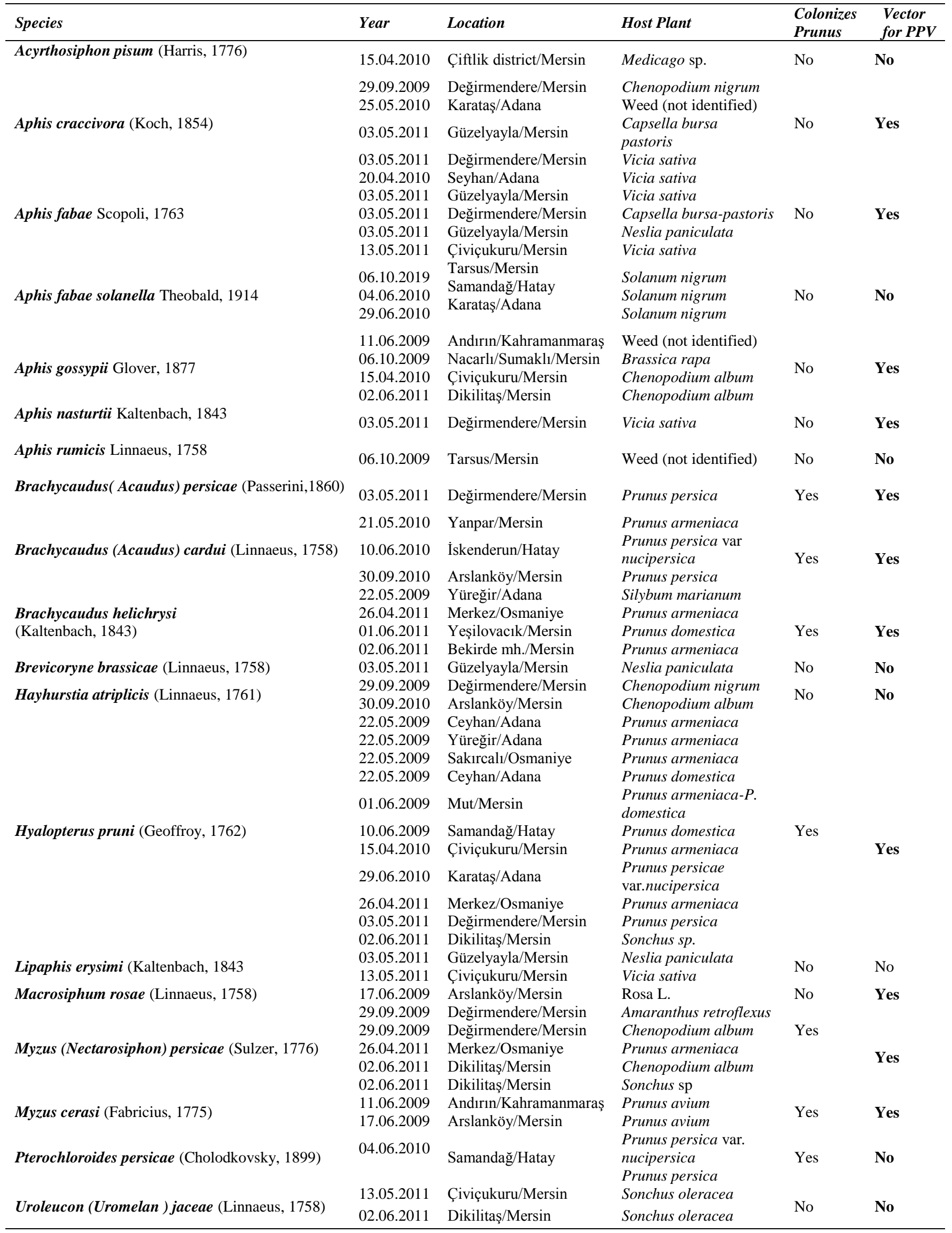




\subsubsection{Results of the first year (2009)}

In the first year of the study, 143 samples were tested for PPV. One orchard located in Adana province were found infected with Sharka disease without any infestation of aphids. The orchards which were infested with aphid colonies were not resulted as PPV-positive. Hyalopterus pruni was the predominant species on Prunus trees in most of the orchards especially in plum and apricot. Myzus persicae was collected from weeds in autumn period. Most of the aphid species detected on the weeds were ranked among PPV vectors. The vector aphids obtained from the stone fruit trees and the weeds detected in 2009 posed a risk for transmission of PPV.

\subsubsection{Results of the second year (2010)}

In the second year, H. pruni kept on being the predominant species on trees followed by Pterochloroides persicae and Brachycaudus cardui. Among 202 samples, only two orchards were found Sharka infected in 2010. The PPV positive orchard in Samandağ/Hatay was infested with peach trunk aphid, P. persicae. Collected samples of $P$. persicae were analyzed by conventional RT-PCR and were resulted negative for PPV. Stoetzel \& Miller (1998) recorded that P. persicae is not listed as transmitting a virus. Labonne \& Dallot (2006) notified that the main sources of inoculum for the vectors are leaves and fruits of infected stone-fruit trees which empowers the thought of P. persicae is not a PPV-vector. Brachycaudus cardui colonies were collected from the second PPV-positive orchard that was located in İskenderun/Hatay. Aphids collected from this orchard were analyzed for the presence of PPV and resulted as positive. This species was cited as the efficient vector of PPV in the previous studies (Brunt et al. 1996; Isaac et al. 1998; Levy et al. 2000). Three aphid species apart from nine; B. cardui, P. persicae and H.pruni, detected in 2010, colonized on Prunus while rest of the aphids were weed colonizing species which most of them were listed in the PPV vectors. In cases where the weeds were infected with PPV, there is a further risk for transmission of the virus from weeds to Prunus spp. by aphid vectors.

\subsubsection{Results of third year (2011)}

In the third year, among a total of 197 samples, five PPV infected orchards were identified in the region. There was not aphid colonization in 3 of them in Hatay. The rest two PPV-infected orchards-a plum orchard in Yeşilovacık/Mersin and an apricot orchard in Dikilitaş/Mersin were colonized with Brachycaudus helichrysi. Although this species is one of the known effective vectors of PPV (Levy et al. 2000), serological and molecular analyzes of B. helichrysi collected from these two orchards resulted negative for PPV. According to this year's result, it is likely to state that the virus was either spread non-homogenously in the orchard or virus concentration was low in the plant part where the aphid fed. In other words, it is seen that the disease may appeared randomly in the orchard and/or spread of the virus may be very irregular in the tree. Besides, the effective spread of virus by aphids varies according to the aphid species, the host species, PPV strain, season and location (Levy et al. 2000). Wallis et al. (2005) reported that for effective PPV spread, timing of optimal host susceptibility, optimal virus titer and optimal vector population should coincide, all of which explains the negative result.

Excluding the two orchards in Mersin, all orchards infected with aphid colonies tested negative for PPV in 2011. Five of twelve aphid species (B. persicae, B. helichrysi, H. pruni, M. persicae, P. persicae) detected in 2011 were Prunus colonizing species and except $P$. persicae all were PPV vectors. Levy et al. (2000) listed $B$. helichrysi and $M$. persicae as the most efficient vector species. Rest of the aphids were non-prunus colonizing species. Among them Aphis gossypii, Aphis craccivora and Aphis fabae were listed as in the most efficient vector category (Levy et al. 2000; Gildow et al. 2004).

\subsection{Detection of weed species hosting aphids and PPV}

Weeds can provide inoculum sources for PPV and act as hosts to aphid vectors as well. In this study, the weed species growing in and around the stone fruit orchards were also collected and analyzed for the presence of PPV. All of them were given negative results against PPV. Both the weed species and the aphid colonies on the weeds were identified into species and listed in Table 3. 
Table 3- The weed species existing in Prunus orchards and aphid species found on weeds

\begin{tabular}{|c|c|c|c|}
\hline Weed Species & Family & $\begin{array}{l}\text { Aphid species present } \\
\text { on weeds }\end{array}$ & Previous works \\
\hline Capsella bursa-pastoris* (L.) & $\frac{\text { Brassicaceae }}{\text { (Syn.:Cruciferae) }}$ & $\begin{array}{l}\text { **Aphis craccivora } \\
\text { **Aphis fabae }\end{array}$ & $\begin{array}{l}\text { Milusheva \& } \\
\text { Rankova 2002, } \\
\text { Brunt et al. } 1996\end{array}$ \\
\hline $\begin{array}{l}\text { Chenopodium album } \mathrm{L} \text {. } \\
\text { Chenopodium vulvaria } \mathrm{L} \text {. }\end{array}$ & Chenopodiaceae & $\begin{array}{l}* * \text { Aphis gossypii } \\
* * \text { Myzus persicae }\end{array}$ & - \\
\hline Solanum nigrum $\mathrm{L} . *$ & Solanaceae & Aphis fabae solanella & Viršček et al. 2004 \\
\hline Medicago sp. & $\begin{array}{l}\text { Leguminosae } \\
\text { (Syn.:Fabaceae) }\end{array}$ & Acyrthosiphon pisum & - \\
\hline Sonchus sp.* & Astaraceae & $\begin{array}{l}* * \text { Hyalopterus pruni } \\
* * \text { Myzus persicae } \\
\text { Uroleucon } * * \text { jaceae }\end{array}$ & Viršček et al. 2004 \\
\hline Sonchus oleraceaus L. & & & - \\
\hline Amaranthus retroflexus $\mathrm{L}$. & $\underline{\text { Amaranthaceae }}$ & $* *$ Myzus persicae & - \\
\hline Neslia paniculata (L.) & $\underline{\text { Brassicaceae }}$ & $\begin{array}{l}\text { **Aphis fabae } \\
\text { Brevicoryne brassicae } \\
\text { Lipaphis erysimi }\end{array}$ & - \\
\hline Silybium marianum (L.) & Astaraceae & $\begin{array}{l}\text { **Brachycaudus } \\
\text { helichrysi }\end{array}$ & - \\
\hline Vicia sativa $\mathrm{L} . *$ & $\begin{array}{l}\text { Leguminosae } \\
\text { (Syn.:Fabaceae) }\end{array}$ & $\begin{array}{l}\text { **Aphis craccivora } \\
\text { **Aphis fabae } \\
\text { Aphis nasturtii }\end{array}$ & Brunt et al. 1996 \\
\hline
\end{tabular}

Four of eleven weed species (Capsella bursa-pastoris L., Solanum nigrum L., Sonchus sp., Vicia sativa) were mentioned as natural hosts of PPV in previous works (Table 2). Families of Brassicaceae (Cruciferae), Chenopodiaceae, Amaranthaceae, Solanaceae and Leguminosae were reported as containing susceptible host plants to PPV (Brunt et al. 1996). Celetti et al. (2008) isolated PPV from several herbaceous hosts such as Ranunculus repens, Medicago lupulina, Trifolium pratense, T. repens, Silene vulgaris that were common weeds in stone fruit orchards in many regions of Ontario. Milusheva \& Rankova (2002) reported that Capsella bursa-pastoris L. was the host of Sharka virus. Viršček (2004) conducted DAS-ELISA analyses to the samples collected from PPV infected peach orchards and found positive results for several common weed species such as Taraxacum officinale, Convolvulus arvensis, Sonchus sp. and Solanum nigrum L. in Slovenia. Chenopodium foetidum is shown as one of the several herbaceous plants which PPV can be artificially transmitted (OEPP/EPPO 2004).

Seven aphid species (Aphis craccivora, A. fabae, A. gossypii, A. nasturtii, Brachycaudus helichrysi, Hyalopterus pruni, Myzus persicae) that infest the weeds shown in Table 2 are PPV vectors. Three of twelve aphid species infesting weeds are also Prunus colonizing species (B. helichrysi, H. pruni, M. persicae) while the rest are not. Not only Prunus colonizing species but also the migratory ones have an important role in the spread of disease. According to the results, it can be concluded that PPV infested herbaceous hosts colonized by vector aphids pose a high risk for fruit trees as PPV inoculum reservoirs. The studies conducted in Prunus orchards and samplings of Prunus trees, herbaceous plants and aphids between 2009 and 2011 indicated that appropriate conditions existed for natural spread of PPV in stone fruit orchards in the region.

Besides, predator species of aphids were detected in the survey areas. Samples were taken from these orchards and were identified into species by experts. The list is shown in Table 4. 
Table 4- Predator species obtained from aphid colonies

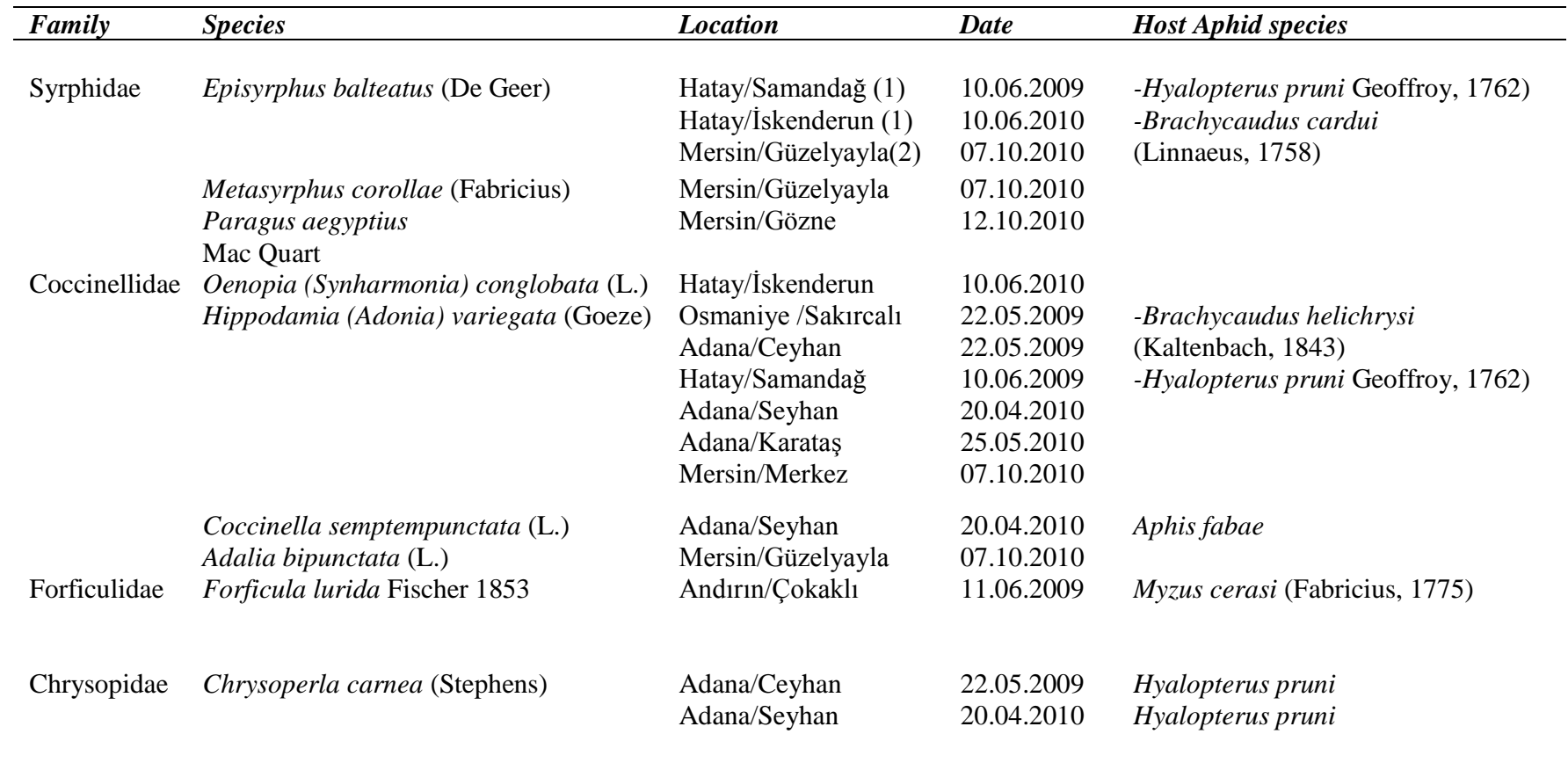

\section{Conclusions}

In this study, the actual status of Sharka disease in stone fruit orchards in The Eastern Mediterranean Region of Turkey were revealed. The orchards tested positive for PPV were eradicated. Aphid species and weeds both in the infected and non-infected orchard areas were detected and the risk of new introductions by aphid vectors were evaluated.

A total of 542 Prunus samples were analyzed for PPV between 2009 and 2011. The survey orchards were located in intensive stone fruit plantings of 5 provinces of the region. Eight orchards tested positive and were eradicated by their owners. Sharka disease incidence was higher in Hatay and Mersin provinces. The PPV infected orchards detected in the region were 3 to 6 years old (the oldest was 10 years old) which set us thinking that the introduction of the disease agent to the region is occurred by infected propagation material imported from abroad or from the other regions of the country. Our results indicated that the prevalence of the disease was restricted in the region. Out of 542 sampled orchards $1.47 \%$ was found infected (Table 1). Another study conducted in Turkey in 56 provinces indicated that the incidence of the disease was 3.9\% in 5.762 samples (Akbas et al. 2011).

According to findings of the study, of the total amount of 19 aphid species detected on Prunus trees and on weeds, six of seven aphid species on Prunus trees and four of twelve aphid species on weeds are PPV vectors. Not only Prunus colonizing aphids, but also the migratory ones have an important role in the spread of the disease. Accordingly, it can be concluded that vector aphids colonized on PPV infested Prunus trees or herbaceous hosts pose a high risk for healty fruit trees as PPV inoculum reservoirs. The studies conducted in Prunus orchards and samplings of Prunus trees, herbaceous plants and aphids between 2009 and 2011 indicated that appropirate conditions existed for natural spread of PPV in stone fruit orchards in the region.

It is a known fact that aphids transmit viruses non-persistently. This can be explained by feeding behaviour of aphids. Although aphids are host-specific in their choice of food sources and plants on which to colonize, they are not capable of identifying suitable hosts visually, and need to probe many plants through tactile and gustatory tests before reaching preferred hosts. When the aphid find the plant (ex.: PPV infected Prunus trees or weeds) distasteful or unsuitable to feed, it moves to a new host (ex.:healthy Prunus), and can in the process, acquire the virus from infected host and then spread it to the healthy ones (Celetti et al. 2008) in a few minutes. Insecticide applications may reduce the overall population of aphid vectors over a growing season but can not wipe off completely. Similarly, predator species detected during surveys (Table 4) and parasitoids can suppress the aphid population but can not wipe off completely. In another word, total control of aphid vectors is impossible to achieve (Anonymous 2008). As a single aphid can transmit PPV to a new host in a matter of seconds, presence of vector aphids in the region pose a high risk for the spread of disease.

Besides, the favorable conditions existed for the natural spread of PPV in stone fruit orchards in the region, the risk of PPVinfected propagation material should not be overlooked. Accordingly, excess responsibility should be undertaken related to quarantine and plant passport implementations. Preventation is the only practical management strategy to avoid sharka disease. Therefore, training of the farmers, officers and all units related with agriculture is as effective as removing symptomatic trees or eradication of the whole infected orchards. PPV infected trees/orchards should be uprooted immediately because natural 
pathways (vector aphids) and the PPV host plants (Prunus and weeds) for the spread of the disease exists in the region. Otherwise aphids are able to transmit the disease to healthy trees in and around the orchard. Infected fruit should also be exterminated because aphids can acquire the virus not only from leaves but also from fruits. Recently, researchers in France and the United States demonstrated that aphids could acquire and transmit the virus from infected fruit to young peach seedlings. Doubtlessly, properly disposing the stone fruit cull piles away from susceptible stone fruit orchards is an important precaution (Celetti et al. 2008). Besides, strict control measures should be taken on the imported plant materials in order to avoid the entrance of PPV infected material to the country or a region.

\section{Acknowledgements}

The authors are very grateful to Dr. Işıl Özdemir, Dr. Eda Aksoy, Prof. Dr. Nedim Uygun, Prof. Dr. Faruk Özgür and Masaru Nishikawa for their identifications. The authors are very grateful to referees for their contribution. Many thanks are due to Biological Control Research Station Adana/Turkey for their financial support.

\section{References}

Akbas B, Değirmenci K, Çiftçi O, Kaya A \& Yurtmen M (2011). Update on Plum pox virus distribution in Turkey. Phytopathologia Mediterranea 50(1): 75-83

Anonymous (2008). Plum pox virus detection. Cornell University. College of Agriculture and Life Sciences. http://web.pppmb.cals.cornell.edu/fuchs/ppv/ppv_detection.html

Avinent L, De Mendoza A H \& Llacer G (1994). Transmission of plum pox potyvirus in Spain. EPPO Bulletin 24: 669-674. https://doi.org/10.1111/j.1365-2338.1994.tb01081.x

Barnett O W (1986). Surveying for plant viruses: design and considerations. In Plant Virus Epidemics: Monitoring, Modelling and Predicting Outbreaks, G.D.McLean, R.G. Garrett, and W.G. Ruesink, eds. (Sydney, Australia: Acedemic Press) pp. 147-166

Bora T \& Karaca İ (1970). Measurement of Disease and Pests on Cultivated Plants. (In Turkish) Eğe Ünv. Zir. Fak. Yard. Ders Kitabı, Yayın No: 167, Bornova/İzmir. 43p.

Brunt A A, Crabtree K, Dallwitz M J, Gibbs A J \&Watson L (1996). Viruses of Plants. CAB International, 1484 p.

Caglayan K \& Yurdakul S (2017). Sharka disease (Plum pox virus) in Turkey: the past, present and future. Acta Horticulture 1163: 69-74. https://doi.org/10.17660/actahortic.2017.1163.11

Caglayan K, Serce C U, Gazel M, Kaya K, Cengiz F C, Vidal E \& Cambra M (2013). Evaluation of the susceptibility of different prunus rootstocks to natural infection of plum pox virus-t. Journal of Plant Pathology 95(3): 579-586. https://doi.org/10.1127/0171$8177 / 2014 / 0019$

Candresse T, Svanella-Dumas L, Gentit P, Caglayan K \& Cevik B (2007). First report of the presence of Plum pox virus rec strain in Turkey. Plant Disease 91(3): 331. https://doi.org/10.1094/pdis-91-3-0331b

Celetti M, Fraser H, Carter N \& Llewellyn J (2008). Sharka (Plum Pox Virus) of stone fruit and ornamental prunus species. Ontario. Ministry of Agriculture Food and Rural Affairs. http://www.omafra.gov.on.ca/english/crops/facts/02-001.PDF

Ceylan A, Gürcan K, Akbulut M \& Sohi M G (2014). High sharka infection in Kayseri. Erciyes University Journal of the Institute of Science and Technology 30: 1-6

Elibuyuk I O (2003). Natural spread of Plum pox virus in Ankara, Turkey. Journal of Phytopathology 151: 617-619. https://doi.org/10.1046/j.0931-1785.2003.00775.x

Gildow F, Damsteegt V, Stone A, Schneider W \& Luster D (2004). Plum Pox in North America: Identification of aphid vectors and a potential role for fruit in virus spread. Phytopathology 94 (8): 868-74. https://doi.org/10.1094/phyto.2004.94.8.868

Isaac M, Preda S \& Marcu M (1998). Aphid species--vectors of plum pox virus. Acta Virolologica 42(4): 233-4

Koc G \& Baloglu S (2006). First report of sharka in the Cukurova Region of Turkey. Journal of Plant Pathology 88(3): 68

Kunze L \& Krczal H (1971). Transmission of sharka virus by aphids. In: Proceedings of the 8th European Symposium on Fruit Tree Virus Diseases, 255-260. INRA, Paris, France

Labonne G \& Dallot S (2006). Epidemiology of sharka disease in France. EPPO Bulletin 36(2): 267-270. https://doi.org/10.1111/j.13652338.2006.00985.x

Labonne G, Yvon M, Quiot J B, Avinent L \& Llacer G (1995). Aphids as potential vectors of Plum Pox Virus: Comparison of methods of testing and epidemiological consequences. XVI International symposium on fruit tree virus diseases, Acta Horticulturae, 386: 207-218 http://www.actahort.org/books/386/386_27.htm

Levy L, Damsteegt V, Scorza R \& Kölber M (2000). Plum Pox Potyvirus disease of stone fruits. APS net features. Online. doi: 10.1094/APSnetFeature -2000-0300. https://doi.org/10.1094/apsnetfeature-2000-0300

Milusheva S \& Rankova Z (2002). Plum Pox Potyvirus detection in weed species under field conditions. VII International symposium on plum and prune genetics, breeding and pomology. Acta Horticulturae 577 p. https://doi.org/10.17660/actahortic.2002.577.48

OEPP/EPPO (2004). Eppo standarts, Diagnostic protocols for regulated pests: Plum pox virus. PM 7/32 (1). Bulletin OEPP/EPPO Bulletin 34: 247-256. https://doi.org/10.1046/j.1365-2338.2003.00629.x

Pirone T P \& Harris K F (1977). Nonpersistent transmission of plant viruses by aphids. Annual Review of Phytopathology 15: 55-73. https://doi.org/10.1146/annurev.py.15.090177.000415

Pribek D (2001). Study on transmission and isolates of Plum Pox Virus, and possibilties of establishing integrated protection. Theses of doctors $(\mathrm{PhD})$ dissertation (published), University of Veszprém, Georgikon faculty of agricultural sciences, Keszthely, https://konyvtar.unipannon.hu/doktori/2001/Pribek_Dalma_theses_en.pdf

Stafford C A, Walker G P \& Ullman D E (2012). Vector feeding and virus transmission. Communicative and integrative biology 5(1): 43-49. https://doi.org/10.4161/cib.18640

Stoetzel M B \& Miller G L (1998). Aphids (Homoptera: Aphididae) colonizing peach in the United States or with potential for introduction. Florida Entomologist 81(3): 325-345. https://doi.org/10.2307/3495923

Sahtiyanc1 S (1969). Virus de la sharka chez le prunier. Bulletin Phytosanitaire FAO 17: 69 
Ulubas Serce C, Candresse T, Svanella-Dumas L, Krizbai L \& Gazel M (2009). Further characterization of a new recombinant group of Plum pox virus isolates, PPV-T, found in orchards in the Ankara province of Turkey. Virus Research 142: 121-126. https://doi.org/10.1016/j.virusres.2009.01.022

Viršček M M, Mavrič I, Zemljič M U \& Škerlavaj V (2004). Detection of plum pox potyvirus in weeds. Proceedings of the $19^{\text {th }}$ international symposium on virus and virus-like diseases of temperate fruit crops pp. 251-254, ISSN 0567-7572, ISBN 9066051485

Wallis C M, Fleischer S, Luster D \& Gildow F E (2005). Aphid species (Hemiptera: Aphididae) composition and potential aphid vectors of plum pox virus in Pennysylvania peach orchards. J.Entomol 98(5): 1441-1450. https://doi.org/10.1093/jee/98.5.1441

Yurtmen M, Hazır A, Gok Guler P \& Fidan H (2017). Attempts to eradicate sharka disease in the Eastern Mediterranean region of Turkey. Acta Horticulture 1163:153-159. DOI:10.17660/ActaHortic.2017.1163.23

(C) 2021 by the authors. Licensee Ankara University, Faculty of Agriculture, Ankara, Turkey. This article is an open access article distributed under the terms and conditions of the Creative Commons Attribution (CC BY) license (http://creativecommons.org/licenses/by/4.0/). 